\title{
British science sent back to dog-house
}

Not for the first time, a British government has revealed its lack of understanding of its scientific enterprise by means of an insensitive reorganization forced by reasons having nothing to do with research.

BRITISH governments do not regard consistency as a virtue, but feel an almost moral obligation to behave differently from their predecessors, and are not ashamed to throw their previous decisions to the winds if convenience so dictates. That is what happened last week with the British government's new arrangements for the administration of the civil science budget (see page 103). At the stroke of a pen or two, British science has gone from being at the "heart of government" (to coin a phrase), with its administration in the hands of the Office of Science and Technology (OST) and its own representative in the Cabinet in the quaintly named Chancellor of the Duchy of Lancaster, to being just another branch of the Department of Trade an Industry (DTI).

Pure malice is probably not the reason why the applecart has been overturned, but it cannot be excluded. It would be more in the tradition of the failure of successive British governments to appreciate the role and sensitivity of science in their affairs that last week's upheaval should have been driven by considerations of administrative tidiness, false as they turn out to be. But whatever the motives, the changes are potentially disastrous.

No doubt in haste to complete a government reorganization made necessary by the Prime Minister's re-election as head of the Conservative Party, those concerned have overlooked the intentions they made public in the 1993 white paper Investing in our future. Then, the same government said that OST would play a part in coordinating and stimulating research throughout government, the DTI included. It was understood that success in this regard would depend on OST's competence, the intellectual force of its arguments and, crucially, the backing of a single-minded minister and even of the Prime Minister.

How does anybody think that possible now that OST has become merely part of one of the government departments whose better articulation with other departments is supposed to be part of its role? The charitable view is that the Prime Minister and Mr Michael Hesletine, now his deputy, have simply overlooked this part of their plan. But Professor John Cadogan, director-general of the research councils, should know better. His promise that it will be "business as usual" for OST can be taken seriously only he implies that its coordination role will be quietly abandoned.

Several worries now arise. How will fundamental sciences such as particle physics and radioastronomy, which cannot even pretend to pay their way by contributing to wealth creation, justify continued support in the new setting? Can it be in the public (or even the government's) interest that scrutiny of decisions on science in the House of Commons will be as attenuated as now seems likely (see page 103)? To whom will the new Science Adviser to the government, Professor Robert May, have access in the new regime and over whom, and what, will he have authority? It is to be hoped that answers to questions like these will be wrung from the government before its thoughtless reorganisation is set in stone.

But no amount of explanation will remedy the chief damage that has been done. The British research community has accepted with a good grace the arrangements introduced three years ago because they promised openness, a sense of partnership between the community and government and the promise that the whole of government science would eventually be judged by the tests proposed for the research councils. A delicate balance, it nevertheless has brought about an improvement of morale in research laboratories everywhere. That is now in hazard. More than mere fast talking will be required to make sure that good spirits do not melt away as quickly as they returned.

The government, of course, will say that these fears are exaggerated. Is not science better off with Mr Michael Hesletine, the most powerful minister in the government, as the ultimate overlord? That is what was said when Mrs Margaret Thatcher (as she was), trained in chemistry at Oxford, was prime minister. She promised to pay personal attention to research, but in the event found she had not the time. Will Hesletine, with the all the government's cares apparently on his shoulders, have more time for science? That seems as likely as that it will "business as usual" at OST.

\section{Physics not guilty}

The 50th anniversary next week of the first nuclear test impells anticipation of the outcome of innovation.

FIFTY years ago next Monday, 17 July, the group of people gathered before dawn at a remote site in the New Mexico desert knew they were to witness an event that would change the world: the first explosion of a nuclear bomb. Scattered in bunkers 10,000 yards from the designated explosion point (called "Ground Zero"), the watchers included many who shaped the development of science in 